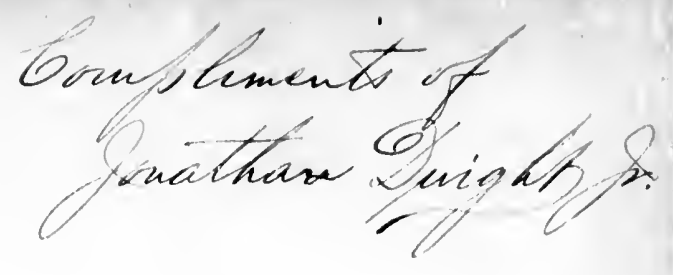

[From 'The Auk,' Vol. X, No I, January, is93.]

SUMMER BIRDS OF PRINCE EDWARD ISLAND.

BY JONATHAN DWGIT, JR. 



\section{THE AUK:}

A QUARTERLY JOURNAL OF

ORNITHOLOGY.

VOL. $\mathrm{x}$.

JANUARY, I 893 .

NO. I.

SUMMER BIRDS OF PRINCE EDWARD ISLAND.

BY JONATHAN WWGHT, JR.

Lyixg in the southern part of the Gulf of St. Lawrence, its low outlines just visible from the mainland, is Prince Edward Island, called by some one the 'Garden of the Gulf.' Compared with the rugged Labrador or Cape Breton coasts of the Gulf. this patch of green on the surromoling blue waters might to a fervid imagination suggest the appellation of garden, but when the clinate, with its long winters and brief stmmers, and the limited productions of the island are taken into account, not to mention the semi-civilized aspect of much of the country, the nime of garden does not strike the belsolder as particularly descriptise. However, it is not my present purpose to do more than indicate the salient features of the island's topography and Hora, that my fellow ornithologists may follow me the more understandingly in my endeavor to introduce to them the avifama of a considerable area hitherto neglected by our fraternity. Anticosti, Newfoundland, Cape Breton, and particularly the Magdalen Islands have all been visited, hut Prince Edwatrd Island hat been passed by, probably because it seemed to ofler fower attractions than these wilder, rengher istands.

Notwithstanding the probability that I should only meet with 
birds whose acquaintance I had alrealy made in other parts of Cimalit, I nevertheless devoted at couple of weeks latst summer to exploring the island, and am now able to saly what species are characteristic summer residents; and a few words albout them may not come amiss to those of us who may be familian with them only during the migration seasons.

The length of my stay was fiom Jume 23 to July 9, and ly means of the narrow-gange railroald. supplemented by horse power, I visited both extremities of the island, making 'Tignish and Sonris my headquarters. The remarkable feat of comnecting these places by 167 miles of railroal has been accomplished (the air line dista'ce is less than 100 miles), the promoters of the roatd being desirous no doubt that each feature of the lindscape should be viewed by the travelling public from at least three diflerent points of the compass. I also stopped at intermediate points. The weatlyer was filsorable, mostly bright, the raw winds from the northeast and the brief rinstorms peculiar to the Gulf being the only disigreealble features, and these were less pronounced as July advanced and the sun gained power. What the climate must be in the winter time, when at belt of ice extending as fir as the eye can reach surrounds the island, and binds it to the manland by ever shifting floes, cin only be inferred from the chilling breath of the northerly breeses that in summer sweep over the frigid water of the Gult. The ice is

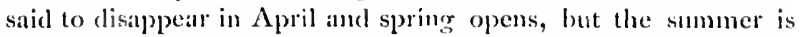
brief and chielly confined to the months of July and August. Brant regularly remain till the Sth of June. With such a backward spring and such a cool and brief summer it is not surprising that agriculture, heyoud the production of hay, potatoes and oats, does not flourish. Com is rarely attempted, and ustully sullers by early frost.

Prince Edward Island hats the form of an irregular crescent, the concavity to the northward. It embraces an area of 213.3 sçuare miles. Its extreme length from East l'oint to West l'oint is about one hundred and twenty miles, and its width would probably average about twenty miles, for the coast line is very much indented by bays. By means of them it is, roughly spealiing, cut into three sections. The westemmost is the narrowest, the width increasing eastward to nearly forty miles. the island tapering ofl again to a point at its eastem extremity. 
The geological formation of the island is a recl, crumbling simdstone that grives rise to low blul!s ten to twenty feet high along the coast, these reaching a height of sixty or seventy fect at some points, notably near North Cape, at East Point, and on the north shore near New Lonilon. 'T'he blutls (or 'clifts' as they are called by the natives) are practically perpendicular, the waves eating them away below, and usually there is a gravelly beach of detritus at their base. They are often guttered by streams, and sloping down, parallel to the water's edge, may be replaced by reaches of gravel or sand, or perhaps low islands, behind which are found lagoons and salt matrshes, but in a few miles, perhaps in a few humdred yards, they may again unexpectedly rise to considerable height. 'The wind-swept sand heaches are ehiefly along the north shore, intermpted at times by the red blulls; and although there is always a pereeptible redetish tinge to the sand, it is surprising how white it may become in some locillities. 'The drifted sand-hills, fringed with more or less scanty grass, suggested the possibility of finding the Ipswich Sparrow, and yet my eflorts were unrewarded, the Savanna Sparrows met with in such places being in no wise lighter-colored th:tn those of adjacent tields.

$\Delta$ green belt of farming comntry encircles the island, the pas. tures in many places extending to the very edge of the blutss, and back of them the land is slightly rolling, nowhere reaching any considerable altitule. The only marked inequalities are due to the erosion of small brooks, and the general ellect is that of a hat country. In the central section, the best settled, the farms extend firom shore to shore and have sueceded the forest that once elothed the whole island. The timber has been nearly all cut, and no large looties remain except in the westem and eastern sections, where bears, still surviving in limited numbers, indicate the nature of the unsettled tracts. A few 'blueberry barrens' vere noticel. Most of the island appears to be well drained and comparatively dry. I met with no extensive swamps, nor are the shores of the fresh water lagoons and lakes (particularly. abundant near East loint) especillly swampy. The lagoons have been made by the damming back of small streams behind the sandbars formed by the wearing away of the blutts. At Tignish the woods were in patches interrupted by fields, this style of country being characteristic of a large part of the islancl. It rep- 
resents here as elsewhere the sprealing of civilization that destroys utterly the forest of its own generation and takes no thought for the possible necessities of the future. Before the woodman's axe, the evergreen forest hats melted awaty in many parts of our continent never to return, its place being taken, as is well known, by decidnous trees, they sullering in their turn, and this process is now well andrancel evea on l'rince Edward Island.

The native trees are chiclly conifera and more than nine tentlus of them spruce (Picca nigra and P. alba) and tir (Abies balsamea). Among the more almumelant deciduous trees atre maples (chietly Acer saccharinum), birches (Bctula lentu, B. lutea, and R. papyrifera, all in considerable numbers), beecles (fragus formginea), and some of the willows and poplars. Of the shruls the heath fimily is well represented, especially by the genera Vaccinium (blueberries), Ledum (Lall)rator teis), and Kalmia ( $\boldsymbol{K}$. angistifolia, sheep laturel). Alders are generally distributed. As to the lerbaceous plants, they are those of the rerthro woods and ficlels. It is said that some plants of the adjacent mainland are not foumel on the island. In other worls, the twenty miles or so of the Stratits of Northumberland act ats a barrier to the possible tinge of more southern forms, and the samse mat influenee the northward range of certin species of birds more or less common on the mainlancl. One maly find liagrant banks of the tiny, noolding Linnca, pistures red with sorrel (Rumex acetosella), swamps blue with iris (/ris acrsicolor), clenrings green with coatrse ferm, beneath which gray mosses and clumps of the searlet bunchbery (Cormes canadensis) may be foumd, and the dirli evergreen wools are carpeted with the greenest of mosses. There are many other trees and bushes, motably latreh (Lariv americana) and arbor vite (Thuya occidentalis) which are rather common locally, but they are not especially conspicuous features, and I merely wish to call attention to certain parts of the florat to indicate in a very general way its charater. There are many tracts of second-growth, ustally almost wholly leech or maple which, if small, are shumued by hirds, and mowhere can one wander fir without entering tracts of timber, from which perhatps only the larger trees have been culled. When fire rums through timber, deid and blackened trunks are left that in a lew years become, by the rotting away of their branclies, the monoto- 
nous dead stubs of the morthern landscape. l'rince Edward Istand is, howerer, rematkably free firm such tracts, having passed this period of primitive civilization. One way of clearing land. especially if it is covered with secomb-growth sproce, is to cut down everything and then let fire do its work when the brush is a little dry, so it is no wonder forest fires are easily started. After fire has swept through a cleariug, raspluery bushes (R. strigosus) and the willow-herly a 'fire weed' (Epilobium angustifolium) are certain to spring 11 , although apparently there may have been nome for miles, coirse ferms soon multiply, and in time the oll stumps and fillen, half-charred logs are covered with mosses and lichens, while the gromud, if not cultivated, is seon hidden by many sorts of plants and grasses. In such spots the Whitethroited Siparow and the slate-colored Junco find their tavorite Iaunts, and here the IJermit 'Thrush makes its nest near the edge of the woods, and sings from some favorite tree. ['erliaps an Olise-sided Flycatcher maty be heard whistling from the top of the tallest dead tree to be found in or near the elearing, or at Wood l'ewee may wander ont from a bit of open woods of mixed growth near by, where also may be heard a Parula Warbler or al Red-eyed Vireo. If maples, birches, and beeches predominate, Ovenbirds will be foumd, and the larger the growth the more probability there is of finding the Black-throated Blue Warbler. The Winter. Wren and the Yellow-bellied Flycatcher abide in the dense evergreen woods along mossy brooks where few other bircls disturt the quiet, save perinaps wandering Wanlers or Thrushes. In elearings grown up with small spruces Magnolia Warblers always abound, and if these trees are of considerable size there are sure to be Olive-backed Thrushes, Biacli-throated Green and Myrtle Warblers. The Nashville Warbler is usually found in the detached, ragged bits of mixed woods, which the Magiolia and Myrtle Warblers also fiequent, together with Redstarts and lhrushes. Such in brief are some of the characteristic birds of the woods, and such their favorite haunts, though their tastes of course maty vary and some, such ats the Hudsonian and Blackcapped Chickadees, the Woolpeckers, and the Golden-crowned Kinglets, are alnost sure to be found in unexpected places.

Then there are (lamp) bushy tracts where the bushes may be waist high and an occasional arbor vite or larch rises above the sinaller growtl. Here one may seek Canadian and Wiison's 
Warblers amd Maryland Yollowthroats, White swampy alders suggest the probalility of finding Traill's Flycateler's and Swamp Sparrows. If at hook passes through the alders, Water-thrushes may be heard, but it is no easy matter to get even a glimpse of them.

The birds of the fields are mumerous, the Saviama Sparrow probibly ontumbering all the others put togetler. Vesper Sparrows and Song Sparrows aloomd, while the Robin and Flicker are more frequently seen in the open than elsewhere. Crows stalk about in every field, though their nests are in the woods. Goldlinches, P'urple Finches, Crossbills and Cedarbirds are generally secn on the wing in the open commtry, and bying higher than the Swallow's (Barn, Bank, and White-bellied) which most frequently are noticed skimming along near the grombl or over the surface of a sheet of water.

Long fimiliarity with the notes and habits of the lirds of the Maritime Provinces enabled me to aceomplish much more than if I had been a stranger to them, and even thongl my stay was brief, I feel confident that those species that escaped my attention were either exceelingly rare or did not occur in the localities I visitel. All males were in full song, and femiales startled from their nests lost no time in beginning to scolel. I was in the field from morning till night, and my gun with its anxilliary wass a trusty friend. Of a previons visit to the island in 1876 little need loe said, for the egr fever was on me at that time and the finding of a Junco's nest was sufficient to satisfy my anbition for several days.

While in Charlotictown I esamined a humeled or more birels stuffed by Prof. S. N. Earle, but unfortmately they lacked data and are therefore of little use in the present comnection. From him, however, I obtained much interesting information. Some notes upon the winter birds of the island have been published by Mr. Bain (Auk, 11, ISS5, pp. 262-267).

I present here a list that embraces only the species that have come under my own observation, but it inclucies most of the l irds that make their summer home on P'rince Edward Island, the fauma of which is thoroughly Cinndian.

Cepphus grylle. Bhack Guntrkmot. - The 'Sea P'igeons' used to breed in great numbers in the cliffs at various points along the coast. I have no doubt that they still do so in sualler numbers, although the only positive 
evidence I have is the fact that I saw a dozen or more of the birds about a clith near New London on the north shore of the island, and heard the young 'squealing' in inaccessible crevices. 'This cliff, extending for perlaps half a mile, is prohably the highest on the island, and is almont sheer to the water seventy or eiglity feet below. No beach here intervenes between its base and the waves which in times of storm beat $\mathrm{ko}$ fiercely. against it that it is justly dreaded by mariners as one of the most langerous spots on the north sliore of the istand. Its crumbling face, to the rery brink of which the green fields above extend, aftords ledges and seams where the 'Sea ligeon' find secure nesting places, nucl are said to be "plenty." I devoted only one day to exploring this locality and did not see many birds. They were in small parties or pairs, lloating upon or skimm,ing over the water, or quittly sitting upon some ledge, the white wing-patch conspicuous against the red background of rock as viewed from a boat. 'Their black bodies were comparatively inconspicuous owing to shadows. At Tignish a boy told me he had found a nest the previous vear in the low blutis of the north shore, and I think they may lureed in the ligh chifls southwest of North Cape, althougl I could not make thorough search. I also saw a pair at East Point where again are high clifts, sixty feet or more in height.

Larus argentatus smithsonianus. Americs IIERrixg Gult. $-\Lambda$ few were seen from time to time, but I could tind noevidence that they bred on the island. Birds of such powerful llight might well wander in the course of a dity many miles from their breeding srounds.

Stema hirundo. Common Tern. - It is prolsable that this species, known as the 'Mackerel Gull,' is the only Tern resident diring the summer months, and it is abundant at many points, particularly the sandy reaches of the north shore. I visited a colony near Souris July 7 , consisting of perhaps seventy-five pairs. Several nests found contained three eggs each, and were the usua", "pressions in the plains of drifted sand, protected possibly by a fix blades of coarse beach-grass and in one case by a few wisps of grass wound round the edge of the hollow. The birls were reserved in their demeanor, but did not hesitate to expose themselves to the danger of firearms when their nests were examined. Their dainty plumage and easy Hight always seem out of keeping with their harsh voices. It is pleasant to visit a colony of 'Terns and realize it has escaped the persecutions of the milliners, for perhaps no one genus of birds has been more thoroughly exterminated in certain sections of our country than has Sterna, thanks to Dame Fashion's inexorable decrees. I was told that this species made its appearance each spring with wonderful regularity on the north shore- usually May 22 - and always between IIty 21 and 24 .

Phalacrocorax _- Two birds were seen at New London, July 2, perehel on a cliff whice with their chalkings, but they could not be approachird. I was told that 'Shays' were often seen on this rock, but were not thosght to breed there. Whether carbo or dilophus it is impossible for me to say. 
Anas obscura. BLACK DUCK, - This is the only Duck of whose presence I have conclusive evidence. I saw a brood on a fresh water lake near Souris, and I found dried up on the sand one day the carcass of an adult. In several other localities I heard of nests having been found.

Botaurus lentiginosus. AMERICAN BitTERN. $-\Lambda$ tolerably common bird in suitable localities, and known by the name of 'Mud-Jen.'

Ardea herodias. Great blue lleron. - I learned of at least two heronries of this bird, but did not visit them. One near Charlottetown was deserilsed to me as containing several hundred birds. The nests were in hard-wood growth, and were warranted to contain young each year by July 4 . The llerons were seen at many points on the island, notably along Sit. Peter's Bay, where 1 saw upwarls of twenty as the train skirted the ahore. They paid litule or no attention to it, although often less than a gun-shot distant.

Philohela minor. American Woodcock. - The sportsmen are acquainted with this bird but it is considered rare. I saw a stulfed specimen, and well recollect the one I shot at I don't know how many times when I visited Ifunter River in 1876 . The country about there is better suited to it than much of the ground visited this time. The partiality of the Woodcock for clean alder swamps still obtains on Prince Edward lsland.

Gallinago delicata. Wilson's SNIpte- This species breeds, sparingly I fancy, at suitable places on the island. I saw a young bird in first phumage ameng Prof. Earle's birds and talked with se gal men who had found nests. The tunsocks in boggy places along brooks seem to be the IIsual site - in one case a nest was found in a bunch of iris.

Actitis macularia. SPOTTED SANDPIPER, - Generally distributed along brooks in the open conntry and fairly common. A nest was found in an odd situation at 'Tignish. It was under a decayed log on a boggy slope, and was carefully lined with bits of rotten wood.

Egialitis meloda. Puring Plover. - Frequented the sandy or gravelly beaches in considerable numbers.

Bonasa umbellus togata. Canimin Ruffel) (jrouse. - A few only were met with, although said to be abundant. $\Lambda$ novel method of lunting them reached my ears. They cone out upon the railroad in a certain section to sun themselves, and it is said the sportsman riding to and fro on a track-velocipede shoots them so that sometimes he can jick them up wilsout stopping. I was informed by gunners that Dendragapus anadensis does not inhabit the island.

Circus hudsonius. Marsil llawk, - Birds of this species were ocensionally seen, recognizable at long dintances by the white bar on the tail. It was almost the only Bird of l'rey met with.

Aquila chrysaëtos. Golues Escis. - I examined a live specimen in young plumage, eaptured June 23, in a fox traj set for it, near New London. The man who caught it thought there was a nen near by in a piece of woods, and expected to trap the old birds as well, one of which he had scen. After visiting the !ocality I an inclined to doubt whether the bird was bred on the island. Eagles are considered rare birds there by all the 
people with whom I talked, and probably stray from wilder regions, such, for instance, as Cape Breton.

Falco columbarius. Pigeon llawk. - A bird that I took to be this species was seen one day. P'rof. Earle slowed me a stuffed specimen.

Pandion haliaètos carolinensis. Amerscan Osprey. - Seen both at Tignish and Souris in limited numbers.

Coccyzus erythrophthalmus. BLACK-BiLled Cuckoo.-One specimen obtained at Tignish is the only evidence I have of its occurrence on the is'and.

Ceryle alcyon. BeLTed Kingfisher. - Tolerably common, making its home in holes dug into the sand stratum that overlies the rock of the bluffs along the shores.

Dryobates villosus. II AIRY Woonpecker. - Occasionally observed. There seemed to be a great dearth of Woodpeckers, the Flicker alone excepted. Dead trees did not abound, still there were a great many of them scattered here and there.

Dryobates pubescens. Dow 'Y WoodPecker. - The only birds I chanced to meet wese a family at Souris ocenpying a hole thirty feet from the ground in a dead maple of large dimensions. The locality was a grove of old maples.

Sphyrapicus varius. Yellow-Belleded SArSucker. - This species was also unexpectedly rare and seldom met with.

Ceophlous pileatus. PrLented Woompecker.-- Sitid to have been forme:'y common. Prof. Earle showed me a stuffed specinen, but I found no other evidence, save hearsay, of its occurrence. No 'mortise holes' were discovered.

Colaptes auratus. Flrcker. - The only aburdant Woodpecter, and found everywhere in 'nolerate numbers. June 25 , a nest with tully fledged young was examined in the top of a hollew fence post. No excavation had been made by the bircl, and the young were entirely exposed to the weather.

Chordeiles virginianus. Niguth day, frequenting the open clearings or sailing high in the air at sunset.

Chatura pelagica. Cumney Swifr. - Rather rare, and not often seen. In a country where a majority of the houses have but one chimney, and that chimney in use from one year's cnd to another's, it is not remarkable that the Chimney Swift still nests in its primitive manner in họliow trees, hot it is rematkable how soon it takes kindly to civilization when this has advanced to the point of building honses with a spareroom chimney.

Trochilus colubris. Ruby-tizonted Hummingir1)-Not observed, but undoubtedly occurs. Prof. Eacle showed me stuffed specinens.

Tyrannus tyrannus. KINGBIRB. - Rather common, and no doubt greatly enjoys life where there are so many Crows to be harratsed.

Contopus borealis. Olive-sided Flycatcikr. - One specimen was observed at Souris. Prof. Earle was familiar with it.

Contopus virens. Woop PEwEe. - Not common, though now and then met with in certain localities, 
Empidonax flaviventris. Yellow-13ELfeled Flicatcher. - Found only at Tignish and in small numbers. The dryness of the other localities visited would partly account for its absence. The searcity of this and the following species mather surprised me.

Empidonax pusillus traillii. 'Tralth's Flycatcuer. $-A$ fell at Tignish in their favorite haunts, the alders, were the only ones met with. It is likely that both this species and the preceding are in some other localities more abundant than my observations would indicate.

Empidonax minimus. Lisst Fuchtcher. $-\Lambda$ cheerful series of 'che-bécs' greeted me one morning at Souris. It is really easier to distinguish this bird from traillii by its notes thas by the bird in hand, but the bird in hand is, unfortunately perhaps, a scientific necessity. No others were seen.

Cyanocitta cristata. BuUE JAY.-Not abur:latt, and only oecasionally met with. No Perisorens conadensis were en heard of.

rCorvus corax principalis Raves.-I was told that at patir of Ravens had formerly nested for several years on the face of the eliff at East Point, and while I think my informant could have made no mistake as to the species, I hesitate about admitting a bird to the list on bearsay only.]

Corvus americanus. AmERICAN Crow.-Nowhere, in the breeding season, have I ever seen Crows so abumdant and so tame. 'They were never out of sight or hearing, and they sit on the fences and 'caw' at you derisively as you ride by. Of course their numbers were augmented by young birds, and early in July they ware beginning to floek, as indieated by a gathering of nearly a hundred seen July 4. At Tignish there was a roost in a large patel of woods, whither towards sundown and later Crows were seen converging from all directions. In the woods a terrible noise was kept up until it grew dark. The Crows do not molest the farmer to any great extent, as he mises no corn, but I was told they kill young ehickens and pick out the eyes of new-borm 1 mbs. They daily congregate for a feast in the fields where the refuse of the many lobstercanoing establishments is used as a fertilizer.

Scolecophagus carolinus. Rusty BLAсквіRD.- - flock of twenty or more, largely young birds, near East Point July 7 , were the only ones seen. I had heard of their occurence elsewhere.

Quiscalue quiscula æeneus. BRoNzed GRACKIE.- $\Lambda$ pair of these birds in l'rof. Earle's prossession were the only ones he hadever seen, very likely stragglers from the mainland.

Carpodacus purpureus. PURPLe Fincil. - Sparingly distributed, a restless and roving species, and seen singly or in pairs.

Loxia curvirostra minor. American Crossbrhl. - Perhaps more abundant than the following species, but the thocks are so often made up of birds of both species, and so much more frequently seen or heard flying overhead rather than allowing a closer examination, that it is diflicult to estimate their numbers. At any rate both were ocensionally seen in flocks of old and young, sometimes one species predominating (usually the flock was almost entirely made up of one species), sometimes the 
other. Although the call notes are quite distinguishable, those of lencoptera being harsher, it is no easy matte: to determine percentages in chattering flocks of a dozen or more birds. Their favorite feediug haunts were larch trees, and, unless disturbed, they were sitent as they hung about the branches in all conceivable attitudes, usually upside down. They also feed on the seeds from the green cones of the fir which are tipped with freshly exuded pitch at this season, if it be a cone yenr. The pitch often mats on the bilis and feathers of the birds. Dissection showed the breeding season to be long past.

Loxia leucoptera. Winte-ivingris Chossint. - Rather numerous. The remarks made under the preceding species apply also to this. Neither can be seen every day, for hoth are gieat wanderers.

Spinus tristis. Anericas Gommincu.-A few seen almost daily.

Spinus pinus. Pane Siskin.-lt surprised me to meet with this species but once-a male at Souris. Dissection showed the bird to be breeding.

Poocæes gramineus. Vegpek Spakiow. - In abundant bird, frequenting the open fietds in the more settied districts.

Ammodramus sandwichensis savanna. SAvANA SpRroow. - It is probably the most abuodant birt on the island, and is found everywhere except in woods. On sand beaches, marshes, or thy fields its weak song was constantly to be heard, and in certitin pastures it seemed ats if every third fence post were occupied by a singer. As an illustration that flying is a matter of practice on the part of young birds, I instance a young Savanna Sparrow that I flushed one windy day in a pasture where the grass was very short. The wind upset all his calculations and himselt as well, apparently getting uncier his wiıgs and turning him upside down cvery time he started on a fresh flight. Ile would get along pretty well for a rod or a and then a puff would send him bowling over the sod till he reached a point of friglit and exhaustion that lelt him panting just where he happened to roll.

Ammodramus caudacutus subvirgatus. AcADtAN SHARr-TAlled) Fincu, $-\Lambda$ few birds in a salt marsh at 'Tignish were the only ones 1 could discover, although I searched in many other tocalities. As Mr. Wm. Stone found this form abundant at Tignish in 1876 (recorded as A. caudacutus, for subvirgatus was not then separnted, Brewster, Buil. N. O. C., Vol. II, Jan. I\$77, p. 28), I wats surprised not to lind it more abundant. I kaw likely ground along East River, but did not have time to explore it, and the birds very possibly mity be locally distributed here and at other points also.

Zonotrichia albicollis. White-THkonted SpAzuow.-This bird so characteristic of the Canadian Fauna is less abundant than the ubiquitous Junco, but on account of its lond and striking song is far better known to the aver, ge inhabitant. It is a bird of the clearings, building its nest upon the ground in a bunch of weeds, and singing nearly all of the time it is not occupied scolding intruders. Its well-known song is easily imitated, and it is amusing to see how angry and excited a male will become if he thinks another has strayed into his own domain. The song 
is sometimes heard breaking the stillness of the night, and only those who have passed a night in the nortsern woods can know how profound this stillnessmay be. The song has given to the bird many local names wherever it occurs, one of the best known being 'Kennedy Bird.' I heard a new rersion which credits him with siying 'Good Lord, pity me, pity me, pity me.' When the young get on the wing, the song is less frequently heard. The bird is known to the few French settlers of the island as rossignol (nightingille).

Spizella socialis. Ciriprinci Sir.skow. - Not a common species, and only occasionally observed.

Junco hyemalis. SicAre-cororen Jusco.-Next to the Samarna Sparrow this is probably the most abundant bird on the island. It is found everywhere, -in dooryards, open fields, fern-clotled clearings, even deep woods. Its nest is on the ground, preferably under something-the bottom rail of a lence or a hole in some grassy bank. Young were just beginning to 1 y. June 23 , and a week later nests with fresh equgs indieated a second laying. Its local name is 'Blucbird,' a strange misnomer, even though Sialia sialis does not occur.

Melospiza fasciata. SoNg SPAk Row. - Very abundaut and general.y distributed. Mr. Bain states that some winter on the island.

Melospiza georgiana. Swimp SpirRow--Rather common in very wet, bushy meadows, with alders here and there, or in open swamps of limited area, such as oceur along brooks in cleared country.

Petrochelidon lunifrons. Cliff Swallow.-A common bird, locilly distributed, and nesting in colonies under the eaves of buns and housen.

Chelidon erythrogaster. BARN SWMLsow.-Abundant and generally distributed.

Tachycineta bicolor. WIITE- Bellaen Swallow.- Fairly abundan! nesting in old Woodpecker holes in elearings, crevices about barts, and the hollow ends of the ails composing the rigzag fences so common on the island. The sudden disappearance of a Swallow as it alighted on a fence was almost startling until I learned that in some deep hollow, decayed out of the heart of an unsplit rail, was a cosy nest of grass and feathers. It was impossible to dislodge the birds that were sometimes out of arm's reach, but several nests examined the last week in June contained young. I have never found this species nesting in such a location before.

Clivicola riparia. BANK Sw.ullow.-I periaps do this species an injustice when I say that it is outmumbered by the Savann: - Sarrow and the Junco. I saw colonies of hundreds at several points along the coast, and as every bluff is crowned by a layer of sand, and much of the coast line is a continuous bluft, the Swallows have unrivalled opportunities for nesting places.

Ampelis cedrorum. Cenarurd.- Seen now and again, lut not common. There is a remarkable similarity between a lisp of this species, a certain note of the Robin, and one of the llermit Thrush.

Vireo olivaceus. RED-EYED ViREo.-A cominon and in a few localities an abundant bird, here as elsewhere a tireless songster. It prefers deciduous trees, particularly large maples. 
Vireo solitarius. - Solitary VIRE0,-At Souris one day I was attraeted by the song of this bird, and sonn saw the performer. This was the only specinen observed on the island. I have often met with it on the inainland, and fully expected to find others, as its rich, clear song, disconnected withal in delivery, cannot fail to attract attention.

Mniotilta varia. Black-AND-white WARnLer.-Oeensionally seen or its 'wiry' song heard, though not very common.

Helminthophila ruficapilla. NAsiville IVARBLer.- Ratlier abundant at Tignish and not met with elsewhere. The activity of this bird is highly commendable, unless you are in pursuit of one, when you are not so favorably impressed. Hardly pausing to dash off its lively song, it is one moment at the very top of some tall tree and the next on the ground a bundred yards away where its song breaks forth quite as vigorously. The bird is the embodiment of restlessness.

Compsothlypis americana. L'IRU1A WARHLER.-Infrequently observed and generally in the upper branehes of hard-wood forest.

Dendroica æstiva. Yallow WARhLR.-Rather common and quite as likely to be found among lonely alder thickets as in the trees around liouses.

Dendroica cærulescens. Biack-THRonted BLUE WARULER.- A few werc detected at Souris. I did not see suel extensive hard-wood timber anywhere clse on the island, and as the species has a decided preference for such loenlities, its absence elsewhere is perhaps not to be wondered at.

Dendroica coronata. Mrrete Warheer.-Common. Their song reminded me of enrly spring days in lower latitudes. Their favorite haunts were chmps of spuces and firs in partly cleared land.

Dendroica macilosa. Magnota WARnLER. - This is the characteristic Warbler of the region and is abundantly represented. It is most abundant in low growths of spruces, where the variety of its song $i_{\text {s }}$ often confusing.

Dendroica virens. BI.ACK-THROATED GREEN WARBLER.-Abundant at every place visited where the torest was composed of trees of considerable size.

Dendroica paimarum hypochrysea. Yellow PALM WARULer.-An incubating female taken at Tignish is the only evidence I have of this bird's oceurrence. The locality was damp, cleared ground, growing up, with bushes and small larches.

Seiurus aurocapillus. Ovennirn.-One was noted at Tignish, and a number at Sonris in the hard-wood timher. It is doubtless fairly common in suitable localities.

Seiurus noveboracensis. WATER-TukUsH. $-\Lambda$ lew were met with at Tignislo only. It is a species that but for its loud song would easily escape notice. Invariably found along brooks or in their near vieinity.

Geothlypis philadelphia. Mourning Warhler.- Apparently rare, though a few were found at Souris in the busby edges of dry fields adjoining the woods.

Geothlypis trichos. MarylaND Yellowturoat.-Found sparingly 
it the wentern portion of the island. None were noted at Somis, aldumugh I have no cloubt they ocen there.

Sylvania pusilla. Wutson's WARnter.-One specimen was secured at Tignish in an extensive arbor-vitie and alder swamp. This is a retiring species and is probably not uncommon if particular search be made for it.

Sylvania canadensis. CANADIA. IVARHLeR. - Rather common about Tignish, but not met with elsewhere, although I have no doubt it occuls in suitable foealities.

Setophaga ruticilla. AmERICAN RuDstare, - Abundant. One of its songs might he easity confused with one of $D$. maculosa. The importance of recognizing songs in a reginn where the denseness of the wooks and underbrush renders the sight or capture of the rocaliot olten well-nigh impossible, is very great, but to depend entirely upon one's ear in identifying birds is a procedure greatly to be depreated.

Troglodytes hiemalis. Wiscrin Wrex. - 'lolerabiy common in daunp woods along brooks, or sometimes in more open localities. On July 6 I met with a fomily of young birds able to ly. That so minute a bird should produce suels a volume of liquid sound is ever to me a source of wonderment. It is often impossible to see the little fellow when he is pouring forth his song right over your head. hut those who have ever entered a dense seeond-growth of apruces, with a witderness of dead iwigs interlacing below, know one of the dilliculties that beset the path of the collector in the northern woods.

Sitta canadensis. Rem-nelonen Nutustew. - l had about given "p seeing this species at all when I came upon several at Souris, probably a family. They feed usually in the upper boughs of spruces, and seldom run up and down the trunks of trees like their white-breasted brethren. They have a thasal cry of one note, uttered with varying intensity, and never rapidly repeated like the other species. Of course I should not venture such general conclusions as these with regard to this species, nor to others, if they were not based upon finther observations made elsewhere.

Parus atricapillus. BLACк-CAPred Cnickajee.-Oecasionally small roving famities were encountered, so that it is probably a faity common species.

Parus hudsonicus. Ifunsonian Cirickader.-Tolerably common, hut not attracting attention to itself so aggressively as does atricupillus. However, when it does speak out, it always seems to me to make use of the ungrammatieal expression 'It's me-e,' with a good deal of emphasis on the 'me-e.'

Regulus satrapa. Golden-Crowned Kingiet. - Infrequently observed. Young were on the wing the last of June. It should have proved much more abundant than I found it to be.

Turdus ustulatus swainsonii. Oluve-Backed Thrtsul. - Very abundant, almost equalling in numbers the Hermit Thrush. They are usually excessively shy and diffieult to obtain, although several may be singing 
witlin hearing at the same time. They frequent thick growths of spruces, and from some commanding perch prome forth therr rich song. If they become aware of your approach even a gunshot or more away, they dive down into the dense undergrowth, and a few soft alarm notes are the last you hear of them. Squeaking to them will bring then to you for one briet look, which satis,ies them, but not you, for they grenerally see you first and at close range. Sometimes they sing in the thicket of spruces, but are more apt to have a particular perch, perhaps on some tcwering, dead tree. I heard no songs that I had any reason to suppose wert other than trut szuinsonit, for the possibility of finding bicknelli or ali-ib had to be kept constantly in mind. I found no young, even up to the last day of my stay but that proves nothing with a lird so retiring. They sang more persistently and in greater numbers in the early morning and late evering hours.

Turdus aonalaschka pallasii. IIERMit Turusu. - Slightly more abundant than the preceding species, and perbaps more grenerally distributed. The songs and notes of this species have been so frequently confused with those of other Thrushes, particularly with those of the Olive-backed Thrush. that an effort on my part to call attention to the differences that exist between them may not be without interest. The deliberate character of its song is in marked contrast to that of swainsonii and its musical ability is more varied. The usual song dies out wilhout the rising intlection of surinsonii, and there is a pause after the first syllable, while in swainsonit there is no pause and the second syllable is strongly accented, the whole song being quickly delivered. The Hermit Thrush has also a nasal note of complaint in two ellided syllables, a eluck like a Blackbird, and a lisp not unlike a Cedarbird. The nasal note has its counterpart in stwainsonii which utters a similar, but more liquid note, and the cluck of fallasii may be compared with a 'puk' or 'pink' (as near as it can be represented) of swainsonii. The lisp is peculiar to pallasii, while there is a queer multiple note of soliloquy peculiar to szu'dinsouii.

Merula migratoria. AMerican RoBis. - very abundant in the more open country. An occasional one is said by Mr. Bain to remain through the winter, stbsisting on the berriez of the mountain ash. 